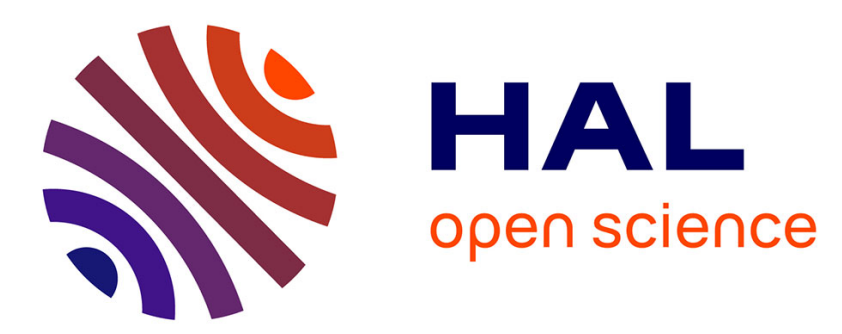

\title{
WHAT PATTERN(S) FOR THE URBAN SPRAWL OF THE POST-SOCIALIST ROMANIAN CITIES?
}

\author{
Alexandra Sandu, Octavian Groza
}

\section{To cite this version:}

Alexandra Sandu, Octavian Groza. WHAT PATTERN(S) FOR THE URBAN SPRAWL OF THE POST-SOCIALIST ROMANIAN CITIES?. 17th International Multidisciplinary Scientific GeoConference SGEM 2017 Jun 2017, Albena, Bulgaria. SGEM2017, SGEM 2017, Jun 2017, Albena, Bulgaria. pp.867-874, 10.5593/sgem2017/23/S11.109 . halshs-01561509

\section{HAL Id: halshs-01561509 \\ https://shs.hal.science/halshs-01561509}

Submitted on 12 Jul 2017

HAL is a multi-disciplinary open access archive for the deposit and dissemination of scientific research documents, whether they are published or not. The documents may come from teaching and research institutions in France or abroad, or from public or private research centers.
L'archive ouverte pluridisciplinaire HAL, est destinée au dépôt et à la diffusion de documents scientifiques de niveau recherche, publiés ou non, émanant des établissements d'enseignement et de recherche français ou étrangers, des laboratoires publics ou privés. 


\title{
WHAT PATTERN(S) FOR THE URBAN SPRAWL OF THE POST-SOCIALIST ROMANIAN CITIES?
}

\author{
PhD Student Alexandra SANDU ${ }^{1,2}$ \\ Professor PhD/Dr. Octavian GROZA ${ }^{2}$ \\ ${ }^{1}$ University of Lyon, CNRS, University Lumière Lyon 2, EVS, UMR5600, F-69007, France \\ ${ }^{2}$ University Alexandru Ioan Cuza of Iasi, Faculty of Geography and Geology, Department of \\ Geography , Romania
}

\begin{abstract}
The urban sprawl has an important impact on the socio-economic evolution of a city as well as on its environment. A defining characteristic of the western European capitalist city, the urban sprawl was not often observed in the urban areas of the Eastern Europe. However, it has become more and more relevant after the $90 \mathrm{~s}$ because the transition to the post-socialist era determined an increasing development of the sub-urban areas of the cities from the ex-communist bloc. This paper studies the case of the postsocialist Romania, focusing on a couple of major cities, trying to underline the different types of urban sprawl that flourished after the fall of the communism, under inconsistent and ambiguous laws. The analysis will be a chronological one starting with the year 1990 and finishing with the year 2015. The period of time is restricted to the availability of the database that will be used, respectively, CORINE LAND COVER. Therefore, the aim of this paper is to identify the spatial and temporal patterns of the urban sprawl in the postsocialist Romanian cities, as well as to test methodologies and also the viability of the CORINE LAND COVER database for this type of analysis.
\end{abstract}

Keywords: urban sprawl, CORINE LAND COVER, Romanian cities, postsocialist

\section{INTRODUCTION}

The urban sprawl has an important impact on the socio-economic evolution of a city as well as on its environment. Yet, despite being a defining characteristic of the western European capitalist city, the urban sprawl was not often observed in the urban areas of the Eastern Europe, before the 1990s. However, it has become more and more relevant after the 90 s because the transition to the post-socialist era determined an increasing development of the sub-urban areas of the cities from the ex-communist bloc. The causes are numerous, being related to the smaller prices of the land in the peripheries, the desire for an individual living lifestyle, as well as the multiplications of the forms of mobility, especially the increasing use of the automobile and one should not forget the demographic causes, even though the latest one is not necessarily true for the postsocialist cities as they had a low or negative natural population growth [9], [10], [11].Moreover, one should consider the fact that in the past 20 years, the built area in Europe increased by $20 \%$, while the population increased only with $6 \%$. [12]. 
Defined in the European Union policy documents as the extensions outside the core city of the residential zones, along with commercial and other various types of zones; all inducing substantial environmental, functional and landscape changes [10], one should note the negative dimension that surrounds it. Often associated with the loss of green and open spaces [1], high level of motorization and air pollution [2], [5], as well as other environmental issues [1],[5] the urban sprawl is an undeniable consequence of the necessity to adapt to new consumption patterns, particularly the need for space and comfort of the population, doubled, generally, by maladjusted urban planning strategies.

Furthermore, as Galster et al. [4] identify, the urban sprawl is a multidimensional phenomenon with a variety of spatial manifestations, such as leapfrog development, ribbon sprawl, commercial strip development, low-density sprawl poly- nuclear growth etc. Therefore, this paper studies the case of the post-socialist Romania, focusing on three major cities: Cluj-Napoca (324576 inhabitants), Craiova (253200 inhabitants) and Brăila (180300 inhabitants), each characterized by different intensities of the urban land dynamics (see fig.1)

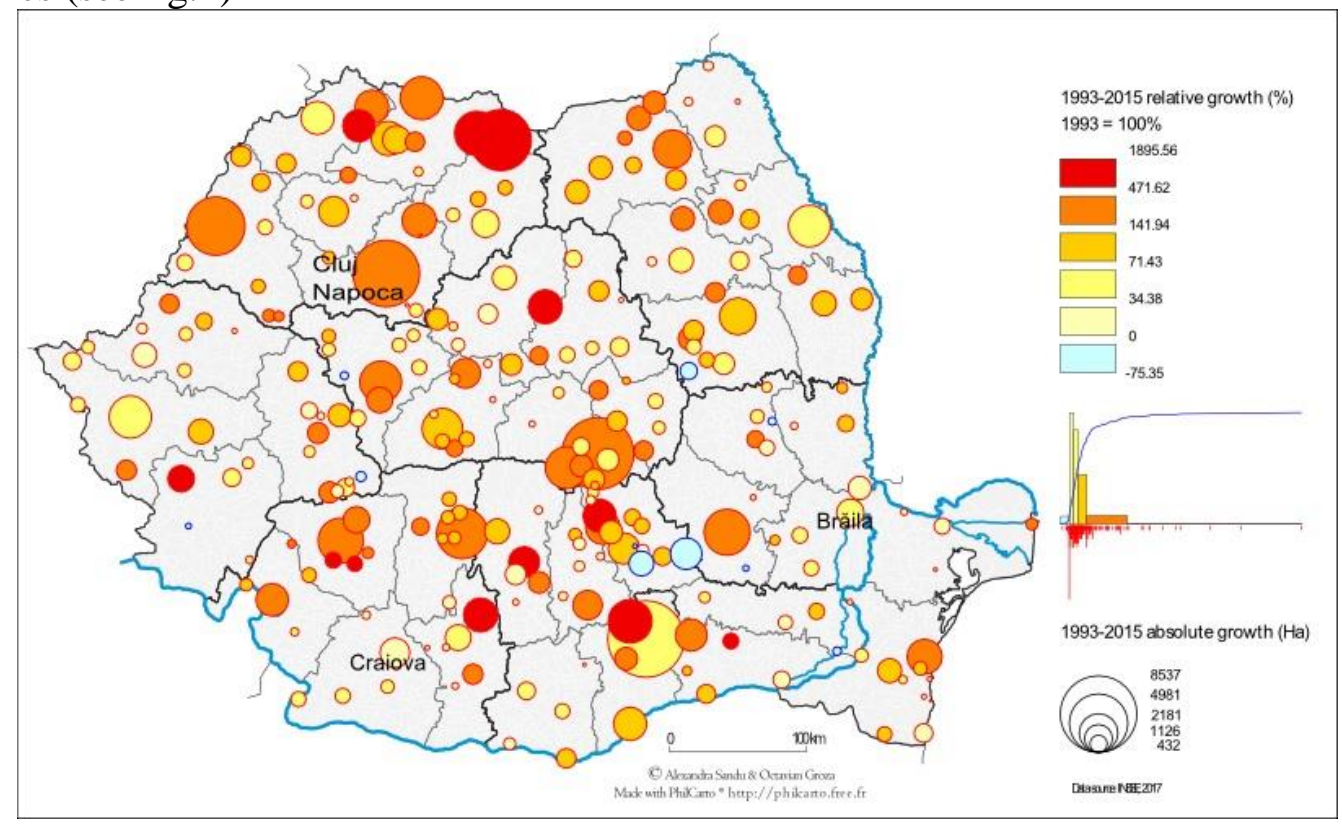

Figure 1 - Dynamics of the agricultural land included in the buildable city boundary: 1993 2015 (Data Source: National Institute of Statistics of Romania)

The main objective is to identify the patterns of spatial changes in what concerns the land-use of the urban areas between the years 1990-2012 in terms of landartificialization of the natural (green urban) and semi-natural areas (agricultural land), but also in what concerns the already impervious surfaces existing in cities such as commercial and industrial ones. It should be noted that the paper focused on the phenomenon of urban sprawl, regarded as the extension of the discontinuous urban fabric (residential use), as well as the conversion of other types of land-use into it over the data frame of the study.

Therefore, the main research questions are as it follows: firstly, it is possible to identify a correlation between the urban sprawl and the growth of population in the three Romanian post-socialist cities? Or the growth of the housing facilities could prove a better correlation? Thirdly, is the agricultural land the most vulnerable in what concerns the phenomenon of urban sprawl? Finally, what specificities, if any could one identify in what concerns the patterns of the urban sprawl in the Romanian post-socialist cities? 


\section{MATERIALS AND METHODOLOGY}

For our study of the urban sprawl in three post-socialist cities from Romania (Brăila, Cluj-Napoca and Craiova) was conducted using the Corine Land Cover(CLC) raster database developed by the European Environment Agency (EEA). As the main focus of this study was the post-socialist urban sprawl, the time period of the study was restricted to the years between 1990 - 2012 for which CLC raster data was available. (resolution of $100 \mathrm{~m} \times 100 \mathrm{~m}$, version 16, 04.2012). The CLC database consists of an inventory of land cover classified in 44 classes, derived from different satellite images.

The three cities were chosen based on their population (small, medium and large city) and also because they each represent a distinct category of urban areas for the post1989 Romania: Cluj - Napoca is an urban area focused on the development of the tertiary services, Craiova merges the socialist industrial heritage with the development of the tertiary services, while Brăila is an urban area where the industrial socialist legacy is still very present. Moreover, as the map in figure 1 shows, they also represent three distinct categories in what concerns the dynamics of the agricultural land included in the city boundary in order to be built on. during the years 1993-2015. It should, however be noted that the map only refers to the cities that exists in 1992, and not to those declared thereafter.

The methodology followed in this paper for the analysis of the three Large Urban Zones (LUZ) (Brăila, Cluj-Napoca and Craiova) has focused on highlighting the changes in the urban fabric using the extracted CLC rasters for the 4 years available (1990, 2000, 2006 and 2012). Therefore, the methodological approach was divided in two main steps. The first step was the preparation of the database - the identification of the classes necessary for the analysis, mainly focusing on the raster reclassification, and therefore assigning new values for each cell containing a type of land-use of interest for the study as it follows: 1 = urban fabric; 2 = industrial areas (IND); $3=$ agricultural land (AGR) and $4=$ green urban areas (GUA), while 0 designated the cells with no interest for this research. The second step consisted in the quantification of the changes that appeared during the period of study, in order to delineate the spatio-temporal dynamics of urban sprawl, using various mathematical operators and functions with the aid of the reclassification tool (Reclassify) as well Raster Calculator Tool from ArcGIS, which allows the aggregation of the new reclassified layers in order to create a new complex layer were the cells with the new values offer information about the changes in the urban landscape. Additionally, in order to get a more in-depth view over dynamics of land-use changes and the susceptibility of the three categories mentioned above to be converted into discontinuous urban fabric, we also calculated the total of the other types of land that were converted into urban fabric during the time of study $(\mathrm{OTH})$. Also, model Builders were implemented, when possible in order to decrease the time and the number of geoprocessing operations.

Furthermore, with the aid of statistics methods the annual percentage of changes in urban land cover (agricultural land, green urban spaces, industrial areas) and demography (population) was calculated for each of the three cities for the years between 1990 to 2000, 2000 - 2006 and from 2006 to 2012. Then, in order to derive the general 
patterns of land-use changes, a percentage of the multi-annual changes was calculated for the three classes of land-use that were studied for the three cities. Further, the percentage of the extension of the discontinuous urban fabric was also calculated being weighted by the city area (large urban zone), in order to reduce any influence of the city area in what concerns the general trend of the urban sprawl dynamics.

\section{RESULTS AND DISCUSSIONS}

The urban sprawl phenomenon represents one of the many challenges of the postsocialist city, a challenge derived from an impromptu and incomplete transition to the liberal regime. We witness an important extension of the residential and commercial areas in the peripheries of the cities [13] as an indirect consequence of the privatization and the transition to the market economy. Moreover a densification of the initial core of the cities, as well as an increased growth of the impervious surfaces to the detriment of the green and open spaces is observed as a result of a loophole in the legacy of the socialist land use plans that placed the entire residential areas in the vague category of « residential use », without differentiating the open and green spaces as an individual type of land-use, therefore the conversion could be made without changing the land-use type as the new legislation demanded [7].Hence, being confronted to a change in ownership in what concerns the majority of terrains and an increased demand from the private market agents, the post-socialist city faced a test in controlling the chaotic spatial development, a test, which due to the communist regime, was not prepared to pass it easily, even 20 years after the 1990.

As all the other ex-communist countries, Romania makes no exception in what concerns the difficulty to control the urban sprawl phenomenon, the urban areas being confronted in the last two decades to an important growth of impervious surfaces. To that end, the analysis of large urban zones of Brăila, Craiova and Cluj-Napoca highlights the spatial dimension of the urban sprawl in the years 1990 - 2012. (see Fig. 3). Hence, for all the three urban areas, it could be observed that the discontinuous urban fabric increased in surface, even though the population which is cited by the literature [3] as being one of the main factors that triggers the urban sprawl, did not increase considerably or it even decreased in what concerns the city of Brăila. (see fig. 3)

Furthermore, the percentage of the extension of the urban fabric for Brăila is $27 \%$, for Craiova $-20 \%$, while for Cluj-Napoca the value is only of $11 \%$. Nevertheless, one could imply that there could be at least some kind of connection between the population growth and the phenomenon of urban sprawl. In fact, the correlation coefficients obtained were as it follows: 0.30 for Cluj-Napoca and -0.08 for Craiova. On the other side, one could argue that the population does not play a definitory role in what concerns the phenomenon of urban sprawl, as shown by the figures for Brăila. In fact, the city that shows quite a rampant sprawl is the city where the population decreased, the correlation coefficient being a strong negative one (-0.70). Yet, this could be explained by the fact that over the last twenty years the city has lost a lot of its population due to an inefficient economic and industrial transition and the population that remained preferred to move outside of the cluttered city center or the former industrial neighborhoods into the peripheral zones. In fact, a better correlation is obtained in what concerns the housing facilities dynamics and the extension of the boundary of the buildable area of the city 


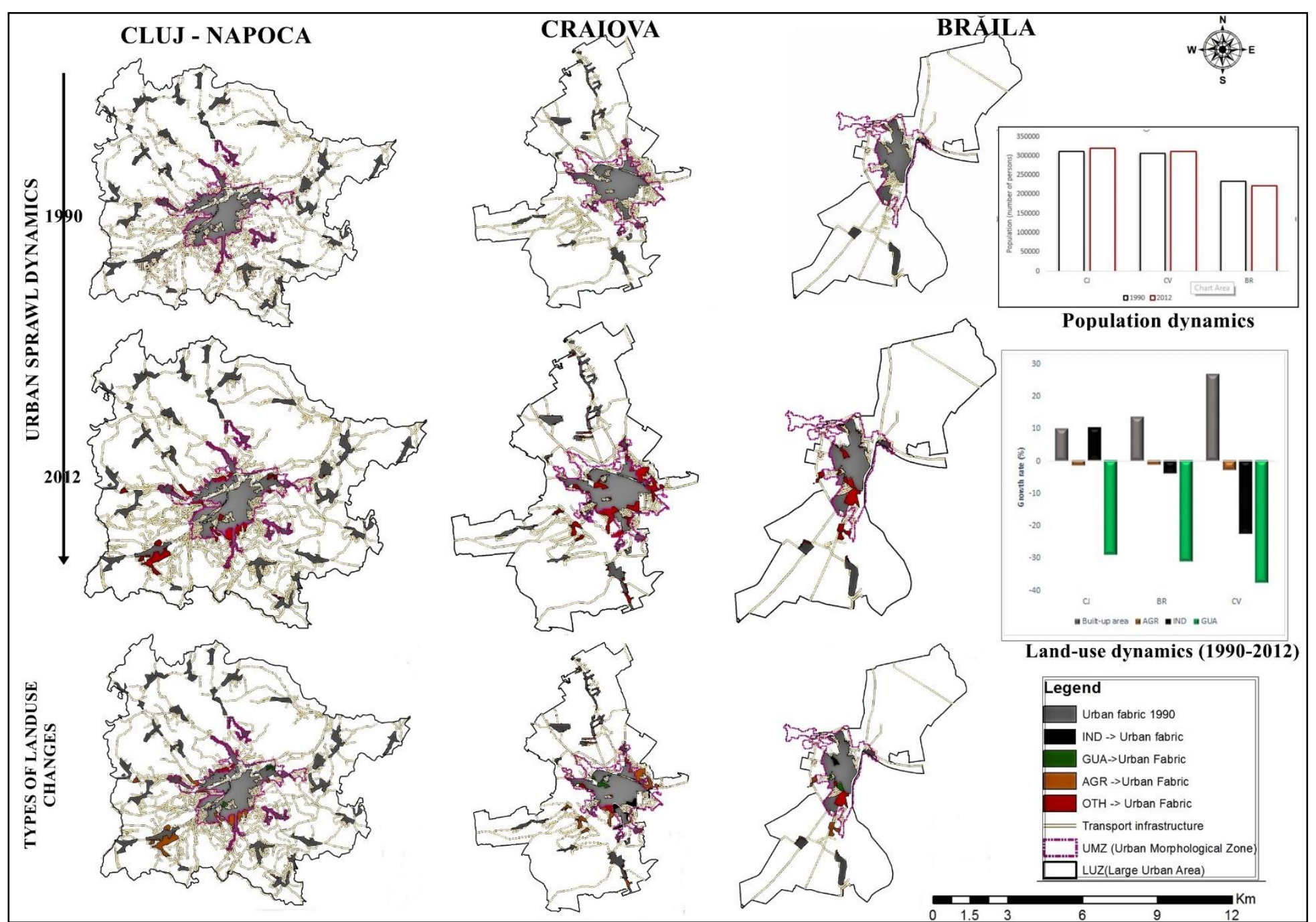

Figure 2 - Patterns and dynamics of urban sprawl and population dynamics in Cluj-Napoca, Craiova and Brăila (Data sources: Corine Land Cover, National Institute of Statistics of Romania) 
(Cluj-Napoca -0.90; Craiova-0,78; Brăila-0,98) proving a paradox: in a country where the demographic dynamics are modest or even tend to drop, the building of the residential complexes is flourishing. (see fig.3)

In what concerns the type of land converted into discontinuous urban fabric, one could note that the most vulnerable category is represented by the green urban areas, followed by the former industrial zones, and finally the agricultural land (see fig.4). Nevertheless, this is contrary to what the literature [6],[8] identifies as the most susceptible land-use category to artificialization (the agricultural areas), at least in what concerns the specificities of urban sprawl in North America and Western Europe.

One could see that the pression to convert the green spaces was and still remains very high. More than $20 \%$ of the land that was converted into discontinuous urban fabric during the last 2 decades is represented by green open spaces for all the three urban areas, emphasizing an important negative effect of the intensive artificialization of the post-socialist era. The pression on the agricultural land does not seem very important, but this could be a false positive result due to the limits of the database used for this study - the low resolution. However, analyzing the patterns of the spatial extension of

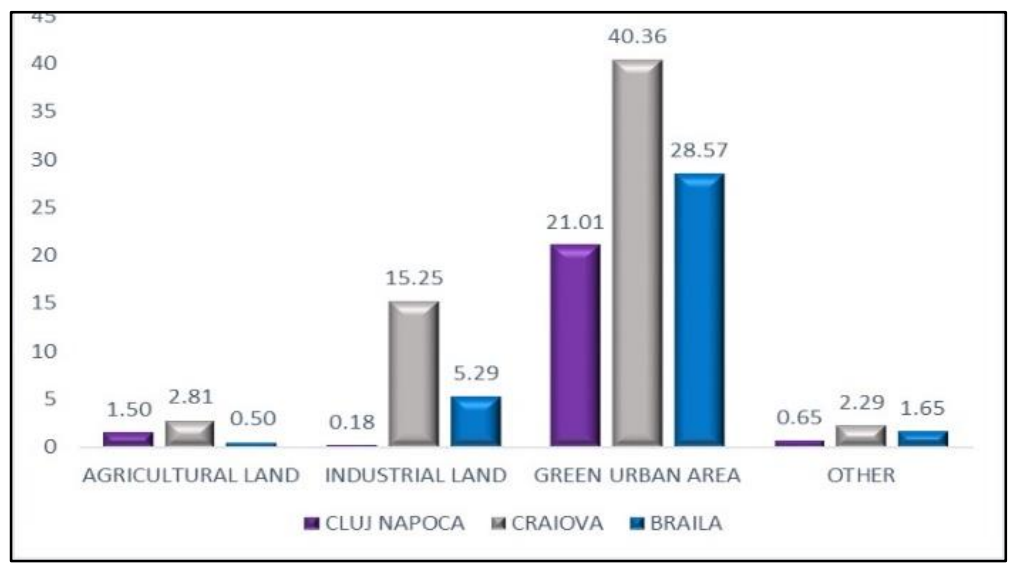

Figure 3 - Percentage of the type of land converted into urban fabric - residential zones (Data source: Corine Land Cover) the discontinuous urban fabric, it can be seen that the most common patterns is the densification of the initial core of the built area (see fig.3), therefore it is logical that the main affected categories of land-use to be the green areas as well as the industrial zones (see fig.4).

In what concerns the conversion of the industrial areas, the intensity of the conversion depends on the efficiency of the tertiarization of the economy and the revalorization of the former socialist industrial zones. In fact, the socialist heritage plays a significant role in what concerns the percentage of the industrial areas converted into discontinuous urban fabric: the more the city was massively industrialized, the more relict industrial areas are nowadays changing their use, if not being abandoned, as the cities do not dispose of the necessary work-force, as well as the raw materials anymore (see Brăila and Craiova).

As mentioned, earlier in the paper, the urban sprawl is a phenomenon with a multiplicity of spatial structures. Thus, in what concerns the spatial patterns of it in the post-socialist Romanian cities, the analysis of the three urban areas allows us to identify the densification of the inner urban area (Cluj-Napoca, Craiova and Brăila), but also the leapfrog development mixed with the linear development along the major transport axis (Cluj-Napoca and modest beginnings for Craiova). One could see that the bigger the city, the more diversified the manifestation of the urban sprawl phenomenon, as it is submitted to a variety of demands from the population. However, it should be also taken into account 
the possibilities that the natural conditions offer in what concerns the presence of different types of urban sprawl. It is logical that for both Cluj-Napoca and Craiova will ultimately evolve towards a poly-nucleated development, as the relief (plain) allows it, while Brăila does not "benefit" from the same "favorizing" elements, the densification of the initial urban core being the "optimal" spatial solution.

To sum up, confronted with an inconsistent legislative basis, a growing anthropic pression (housing and market demands), the three post-socialist cities which were analyzed became the "ideal terrain" for the flourishing of the urban sprawl phenomenon. Despite using a database with a resolution that may not allow us to capture in detail the phenomenon of urban sprawl, at least in what concerns the categories of land affected by it, this being a limit of this study, one cannot deny the fact that the database allowed us to compute general spatial metrics which permitted the observation of the general trend of the evolution of the urban form over time, emphasizing the increased trend of spatial extension of the urban fabric.

\section{CONCLUSION}

To conclude, the phenomenon of the urban sprawl should be considered one of the main challenge of a world, where more than half of its population lives in highly urbanized areas. If taken into account also the fact that it poses a threat to the intensively promoted sustainable development, one could see the importance of why we need to address and deal with it.

The results obtained from the analysis of the three case studies stress out the fact that, for the Romanian post-socialist cities, the urban sprawl is an undeniable phenomenon which is generally associated with the building of new residential areas outside the limits of the built-up area inherited from the socialist era, as the population tried to escape the confinement of the continuous and suffocating urban fabric. Moreover, one could not find a defining correlation between the population growth and the phenomenon of the urban sprawl. A stronger correlation (close to 1 - see Brăila) was observed for the growth of housing facilities in connection with the urban sprawl, proving on one hand that the residential extension is the main type of sprawl for the Romanian post-socialist cities, and also on the other hand that the extent of the built space in a context of a modest and / or negative demographic dynamics illustrates the particularity of the urban expansion in Romania , fact that could be extended even to Eastern Europe; Therefore, the urban expansion is not in fact a direct consequence of the growth of the population, but of the development of the individual housing preferences, amid the rise of the middle class . Consequently, in order to convey to the sustainable development that is nowadays promoted worldwide, the Romanian legislation, as well as the operational tools need to be rethought and readjusted in order to obtain an effective urban planning. In fact, ensuring the coherent development of peri-urban areas is a key element in ensuring not only a high level of quality of life for the population, but also a territorial cohesion for the hinterland, bringing into attention a better management of the urbanrural relationship and limit the urban sprawl.

All in all, Romania still remains a geographic "entre-deux" which tries to mimic the model of the western neo-liberal city, but in the same time it has to deal with the variety of the issues derived from a chaotic transition, which created forms without substance, the quasi-uncontrollable urban extension being in fact one of them. 


\section{REFERENCES}

[1]. Barnes, K. B., Morgan III, J. M., Roberge, M C., and Lowe, S. Sprawl development: Its patterns, consequences, and measurement. Towson University.http://chesapeake.towson.edu/landscape/urbansprawl/download/Spra wl_white_paper.pdf, 2001

[2]. Batty, M., Xie, Y. and Sun, Z. The dynamics of urban sprawl. Working Paper Series, Paper 15, Centre for Advanced Spatial Analysis, University College London. http://www.casa.ac.uk/working_papers/, 1999.

[3]. Bhatta, B. Analysis of urban growth and sprawl from remote sensing data, Advances in geographic information science. Springer, Berlin, 2010.

[4]. Galster, G., Hanson, R., Ratcliffe, M. R. et al. Wrestling sprawl to the ground: defining and measuring an elusive concept, Housing Policy Debate, 12(4), pp. 681-717. (http:// www.fanniemaefoundation.org/programs/hpd/pdf/ HPD_1204_galster.pdf), 2001

[5]. Gillham, O., MacLean, A.S. The limitless city: a primer on the urban sprawl debate. Island Press, Washington, DC., 2002

[6]. Hasse, J.E., Lathrop, R.G. Land resource impact indicators of urban sprawl. Applied Geography 23, 159-175. doi:10.1016/j.apgeog.2003.08.002., 2003

[7]. Hirt, S. and A. Kovachev . The changing spatial structure of postsocialist Sofia. In S. Tsenkova and Z. Nedovic'-Budic' (eds.), The urban mosaic of post-socialist Europe, Physica Verlag,Heidelberg. Johnston, R., M. Poulsen, 2006

[8]. Kasanko, M., Barredo, J.I., Lavalle, C., McCormick, N., Demicheli, L., Sagris, V., Brezger, A. Are European cities becoming dispersed? Landscape and Urban Planning 77, 111-130. doi:10.1016/j.landurbplan.2005.02.003., 2006

[9]. Sandu A. Mapping the spatial patterns of the urban sprawl in Central and Eastern Europe. What particularities for the post-socialist city ?, 16th International Multidisciplinary Scientific GeoConference SGEM 2016, www.sgem.org, SGEM2016 Conference Proceedings, ISBN 978-619-7105-60-5 / ISSN 13142704, June 28 - July 6, 2016, Book2 Vol. 3, 319-326 pp;DOI: 10.5593/SGEM2016/B23/S11.041;http://sgem.org/sgemlib/spip.php?article8547 \&lang=en, 2016

[10]. Suditu, B., Ginavar, A., Muică, A., Iordăchescu, C., Vârdol, A., Ghinea, B.Urban sprawl characteristics and typologies in Romania. Human Geographies - Journal of Studies and Research in Human Geography 4, 79-87., 2010.

[11]. Tsenkova S., Nedović-Budić Z. The Urban Mosaic of Post-Socialist Europe: Space, Institutions and Policy, Heidelberg/New York: Physica-Verlag, 2006

[12]. EEA Report - Urban sprawl in Europe - the ignored challenge, no 10/2006, 2006

[13]. ESPON report - Urban-rural relations in Europe, 2006

[14]. EEA Datasets : CORINE LAND COVER datasets - http://land.copernicus.eu/paneuropean/corine-land-cover/; EU-DEM dataset - http://www.eea.europa.eu/dataand-maps/data/eu-dem

[15]. INS - National Institute of Statistics of Romania (statistici.insse.ro/shop/?lang=ro) 